\title{
Civilisations
}

Revue internationale d'anthropologie et de sciences

humaines

$50 \mid 2002$

Itinéraires belges aux Amériques

\section{Maya warfare: sources and interpretations}

\section{Dirk Van Tuerenhout}

URL : http://journals.openedition.org/civilisations/3400

DOI : 10.4000/civilisations.3400

ISSN : 2032-0442

\section{Éditeur}

Institut de sociologie de l'Université Libre de Bruxelles

\section{Édition imprimée}

Date de publication : 1 décembre 2002

Pagination : 129-152

ISBN : 2-87263-180-1

ISSN : 0009-8140

\section{Référence électronique}

Dirk Van Tuerenhout, « Maya warfare: sources and interpretations », Civilisations [En ligne], 50 | 2002, mis en ligne le 01 décembre 2004, consulté le 30 avril 2019. URL : http://journals.openedition.org/ civilisations/3400; DOI : 10.4000/civilisations.3400 
MAYA WARFARE: SOURCES AND INTERPRETATIONS

\author{
DIRK VAN TUERENHOUT
}

Our appreciation of the Pre-Columbian Maya has changed considerably over the last fifty years. Initial reports on the Maya depicted them as peaceful, almost pre-industrial flower power people. Maya centers served an organized priesthood, while the peasantry came in at regular intervals to provide food to their theocratic leadership and to receive admonitions and advise in return. Half a century worth of data collecting has changed this view. We now have a much better understanding of who the Maya were. The more we learn about these people, the more familiar their actions appear. One facet of Maya behavior that ought to look familiar to us is warfare.

In the following pages, I will discuss three data sets on warfare: texts, iconographic representations and material remains. However, these rich sources of information need to be evaluated with caution, and it is with these caveats that I will start.

WRITTEN SOURCES

There is no substitute for written sources in reconstructing the past. Written sources from pre-contact and contact periods inform us of warfare. Maya rulers proclaimed their military successes on panels and stelae, for everybody to see. Spanish chronicles relate the bloody combat which ensued when the Spaniards decided to conquer Yucatán. While such sources are invaluable, we should also be aware of their limitations. Colonial records suffered from a double disadvantage: they were sometimes drawn up many centuries after the Classic period, essentially describing a Postclassic society in disarray. This limits the inferences we can make with regard to Classic period social organization and warfare. Moreover, such sources also tend to embellish the Spanish exploits, while perhaps painting an oversimplified picture of their opponents. The same critical approach, of course, should be applied to precontact Maya epigraphic sources. They too looked at the world from a skewed perspective. However, they do have a double advantage: some inscriptions were closer in time and space to our subject of study: the Late Classic Maya. 
Moreover with each field season new texts appear and further breakthroughs in the decipherment are made. Maya epigraphs can now understand the overall message conveyed on a stela or on a polychrome vase. We have come to appreciate the information these texts impart on political organization, regional alliances, and warfare in a way only dreamt of a few decades ago. I will confine myself in the following pages to data pertaining to pre-contact warfare.

\section{Epigraphic texts}

The epigraphic record contains numerous references to wars. On the basis of the inscriptions, it seems that warfare became more important in the Late Classic period (Sharer 1994:143; Stuart 1993:333). Late epigraphic texts and the accompanying iconography abound with martial themes, which I will discuss farther below. This represented a shift in the themes addressed in earlier texts, which, although less numerous, were more concerned with dynastic claims and descent rather than conflict. There are, however, some exceptions.

One possible exception was Stela 5 at Uaxactun. It was dated to 8.17.1.4.12, or January 13, 378 A.D. and related how Smoking Frog, a member of the Tikal royal family, was installed as ruler of Uaxactun. We do not know whether this event was the result of inter-site warfare or a royal marriage. Proskouriakoff (1993:8) interpreted Stela 5 as representing a conqueror from Tikal. Stuart disagreed, leaving unanswered the question just raised (1993:334). Others leave both possibilities open (Matthews 1985:44; Sharer 1994:185). Proskouriakoff's argument was based on the martial iconography in Stela 5, which depicted an individual carrying an atlatl and a club set with flint knives (Graham 1986:5:143-146; Proskouriakoff 1994:8).

Less than ten years afterwards, about 385 A.D., Tikal may have been involved in the execution of eight or more elite individuals at Río Azul. These executions were depicted on three round altars found at Río Azul (Sharer 1994:192). The executions must have been part of Tikal's conquest of Río Azul (Sharer 1994:194, 265, Table 5.2). A last example comes from the tread of Block II in the hieroglyphic stairway 3 at Yaxchilán. It allegedly contained a reference to Yaxchilán defeating Lacanha in 564 A.D. (Culbert 1988:139; Graham 1982:3, 168; Hassig 1992:220; Tate 1992:256, 271).

The epigraphic record is replete with references to warfare during the Late Classic period. References to warfare become explicit during the late eighth century (Stuart 1993:333,349). The Maya distinguished between military actions taken against a site and those taken against an individual. A campaign against a site was indicated by a "shell-star" glyph. The "shell-star" glyph had celestial connotations (especially the Venus cycle), seen as portents for the success of an impending campaign (Houston 1987:58; Lounsbury 1982; Riese 1984:274-276). This glyph was often associated with a specific set of costume elements worn by Maya warrior-rulers (Schele and Miller 1986:213; Baird 1989:105). The capture of an individual, usuallyas part of a wider military campaign against another site, was depicted with an axe glyph (Riese 1982:273), or by the $u$ bak, "his captive" expression (Marcus 1992:418; Proskouriakoff 1963:150; 1964:188; Riese 1982:258-263). The axe 
glyph reads most likely as $c h^{\prime} a k$, "to chop", an ominous reminder of the fate that awaited the captive (Stuart 1992:176). Regarding the depiction of prisoners, Proskouriakoff made an important observation while studying the Yaxchilán imagery: "[T]hough I speak here of the captives as if they were individual men, I hold the reservation that they may be representatives or even embodiments of tribes or towns" (Proskouriakoff 1963:150).

In addition to the two expressions just mentioned, $u$ bak and $c h ' a k$, we know of other concepts and words related to war. For example, Maya texts may have referred to military ranks as well. Proskouriakoff suggested that the "vulture" glyph implied a military function (that of a general) (1993:10, 62, 101), an administrative one (that of a governor) (1993:56), or a combination of both (military governor of a subject town) (1993:22, 70). Also, the jaguar glyph, in association with the parrot-feather glyph, may refer to a military order, similar to the "vulture" glyph (Proskouriakoff 1993:104). Finally, a rank in the army may be referred to by the double cauac sign (Proskouriakoff 1993:57).

This rich data set has shown how war during the Classic period did not always lead to the incorporation of the land of the vanquished into the realm of the victor. Moreover, warfare was a very potent source of ideological and secular power for the rulers, especially when massive transfers of land, people and goods were involved. Finally, it has become apparent from the written record that the Maya elite used warfare as an important tool of culture change (Fash and Stuart 1991:167).

The Maya differentiated between hostilities against a site versus hostilities against a particular individual. The former was signaled as a "shellstar" event, the latter appeared on Dos Pilas Stela 1 (Houston 1987:51, n. 9). Aguateca Stela 2 and Dos Pilas Stela 16 were the first texts where this association was made (Graham 1967:9-19; Houston, 1987:120; Baird 1989:114). Both carry dates of 9.15.4.6.4. (November 29, 735). Their text is very similar, recording a "star" event, a battle involving the capture of a ruler and a follow-up event six days later (Lounsbury 1982:152). An initial interpretation by Proskouriakoff that this might refer to "some sort of raid on Tikal by joint forces from Seibal and Aguateca" (Graham 1967:19) was later changed into a campaign against a lord of Seibal by Ruler 3 of Dos Pilas (Riese 1982:275; Johnston 1985:53; Houston 1987:58-59; 1993:115).

Another famous instance of inter-site warfare attested in the epigraphic record is that between Caracol and Tikal. Altar 21 at Caracol relates two successful engagements against Tikal, in 556 A.D. and 562 A.D. (Chase and Chase 1987:60-61; Culbert 1991:135).

One of the primary goals of warfare seems to have been the taking of captives. The "axe-events" and the title of "ah bak," or "holder of captives" in the written record point to this aspect (Marcus 1976:135-136; Proskouriakoff 1993:72; Riese 1982:272-274) ${ }^{1}$. Its iconographic component, the representation of captives, is elaborated on below, in the section on iconography and warfare. The Maya also had a term for "contingent of soldiers," the katun sign (Fox 1987:133; Coggins 1980:733; Proskouriakoff 1993:56, 61, 132-133, 140).

Logistical restraints operated in Maya warfare as well. Written sources indicate that Maya warfare rarely engaged in long-distance campaigns (Hammond 1991:17). The mean distance between centers recording war is $49 \mathrm{~km}$, a distance 
one could cover in two days, perhaps even one day by river (Hammond 1991a:277). This correlates well with Early Postclassic incidences of warfare, when Maya sometimes called upon kin up to $20 \mathrm{~km}$ away for aid in battles (Fox 1989:675, n. 17; see also Fox 1987:32-33).

\section{ICONOGRAPHIC SOURCES}

In addition to written sources, we can also rely on artwork to study warfare. Furtunately, several mural paintings depicting conflict have survived. To judge from the frequency of known iconographic depictions of warfare, it seems that war occurred more commonly during the Late Classic than during the Early Classic (Miller and Houston 1987:50). Whatever their temporal designation, these representations not only complement our written sources, they also provide us with a glimpse of warfare before the arrival of the Spaniards. Of the wide array of warfare imagery, I will discuss murals first and then carved monuments.

\section{Murals}

One of the best-known murals with a martial motif is the one in Cacaxtla, especially the painting in structure B (Baird 1989:108; McVicker 1985:84). Stylistic evaluation and radiocarbon dates associated with the paintings date them to between 655 and 835 A.D. (Baird 1989:105)'. The interpretation of what we are looking at varies. Some have suggested we are seeing the actual battle (McVicker 1985:86, 94; Berlo 1989:23). Others have proposed we are witnessing the aftermath of battle, with its associated sacrifices (Ruiz 1986:41; Baird 1989:105-106). However, the iconography leaves no doubt these paintings relate to conflict.

The figures carry all kinds of weaponry, such as spears, atlatls, obsidian knives, and shields (Baus de Czitrom 1986:529-530; Ruiz 1986:221, Figures 166-177, 179-192). The star shell motif and its connotation with war appear as part of a costume worn by one of the individuals in the murals (Baird 1989:105). Two sets of warriors can be identified on the basis of differences in accoutrements (McVicker 1985:86), iconographic elements associated with persons (McVicker 1985:95), as well as physical types (Lopez de Molina 1979:464). Iconographic studies of all the Cacaxtla murals point to the importance of sacrifice in relation to warfare, intimating blood sacrifice was one of the aims of battle (Baird 1989:119; Schele and Miller 1986:214, 221 n. 8 ).

There is no agreement among archaeologists and art historians as to whether or not these paintings represent a historic event. Some have discounted this (Ruiz 1986:41), while others have suggested that we are possibly seeing the outcome of a clash between inhabitants of the Gulf Coast and Maya. The most likely place for such a battle to take place, it has been suggested, was the southern Veracruz or Campeche region (McVicker 1985: 98; Baird 1989:119).

Another set of mural paintings of equal importance is the murals of Bonampak. They consist of a number of narrative scenes depicting preparation for battle, the battle and the aftermath (McVicker 1985:94). Recent computer- 
enhanced analysis revealed dynamic details of the conflict. We can see how one individual is grabbed by the hair and pulled down. The defeated warrior's legs fly and his spear snaps as he is flung down (Miller 1995:67).

In 1901 and 1902, Adele Breton copied mural paintings found in the interior of the Upper Temple of the Jaguars, in the ballcourt group at Chichen Itzá. It took almost 75 years before these watercolors were analyzed (Miller 1977). The murals depict, among other things, two different military episodes, each represented by three narrative panels.

The murals at Chichen show one encounter set in a hilly territory. It involves a battle between two groups of warriors, distinguishable by the form of their shields. One group of warriors is shown occupying the base of a hill, while the others are in control of hilltops above (Miller 1977:211). The men on the hilltops are rolling down boulders onto the troops below. It seems the attackers were successful, since in parts of the mural we can see how some of the defenders were retreating across a bridge connecting two hill tops (Miller 1977:204, Figures 5, 211; Coggins 1984:158, Figure 17). The drawings also reveal a village built on hilly ground, with the same two groups of warriors involved in conflict (Miller 1977:211). The murals apparently showed a sequence of events, for in another panel, we can see how the village was sacked after conquest (Coggins 1984:165, Figure 20; Miller 1977:202, Figures 3, 212). It is possible that these drawings depict the conquest of a village possibly in Oaxaca, based on the presence of the red hills (Miller 1977:212-214). Others have suggested the red hills refer to the Puuc (Robles and Andrews 1986:84; Dunning 1992:152).

A second set of narrative panels at Chichen Itzá depicts another village scene located in a hill and gully setting. The vegetation points to a tropical environment (Miller 1977:214, 218). The first of the three scenes show soldiers in various stages of preparing for battle, including possibly preparing or repairing canoes (Coggins 1984:163, Figure 19; Miller 1977:206, Figures 7, 214). Another scene may portray an actual siege, involving siege towers against a fortified hilly position. Standing on these scaffold-like constructions are soldiers throwing their projectiles at their opponents. Some of the warriors have jumped off the towers into the fortification and are battling the defenders (Coggins 1984:159, Figure 17; Miller 1977:207, Figures 8, 215). Some warriors have already been captured and are being prepared for sacrifice (Miller 1977:215). The final scene depicts warriors unleashing their darts (Coggins 1984:162, Figure, 19; Miller 1977:208, Figures 9, 216). It is unclear, however, if actual combat is shown here, or rather a portrayal of the military capabilities of the two groups. We might even be looking at a manual of military drill (Miller 1977:216). The village scene in the same panel shows conquest and exile. Women carrying their belongings on their back are leaving the village, looking back in despair at their dwellings (Miller 1977:217). Considering the more tropical scenery it is possible these scenes depict events that occurred in the Maya lowlands, perhaps in the Petén (Miller 1977:218; Wren and Schmidt 1991:209).

Dating these mural paintings is problematic in more than one way. The date of the structure in which they were found is disputed. Parsons (1969) favors a seventh-century date for the construction, while others assign this to a later period (Kubler 1962:148). 
Other examples of late monuments featuring martial imagery would include Kabah Altar 8 and the sculptured doorjambs from Structure 2A3 and Structure 2C6 (Codz Poop) at Kabah (Pollock 1980:Figures 333-334, 372-373, 381). The late monument, Stela 21 at Oxkintok, features a prominent warrior in the central panel (Pollock 1980:Figure 547). The most obvious emphasis on warfare and captive taking is at the Nunnery Quadrangle at Uxmal where warrior figures and naked and bound captives adorned the facades of the North and West structures and appear as graffiti in the South building (Foncerada de Molina 1965:151152, Figure 38; Kowalski 1987:165-166; 1990:29, Figures 5-7; Seler 1917, Abbildung 47, 52; Dunning and Kowalski 1994:81, n.11.)

\section{Carved monuments}

Iconography of warfare appears on carved monuments as well. This set of monuments includes stelae, altars, lintels, and panels. These monuments usually refer to warfare in two complementary ways: through a text component - as discussed earlier - and a graphic representation. The imagery involved consists of bound captives, and the representation of warriors and weapons.

An early example of a depiction of bound captives is Lintel 12 from Piedras Negras, dating to the beginning of the sixth century A.D. (Proskouriakoff 1993:29). In the Late Classic period, at times when royal power is declining, carved monuments sometimes carry blatant propaganda messages. As noted earlier, at Copán, the final ruler is shown brandishing shield and lance on his last known carved monument. This representation is quite a departure from his previous monuments, and implies serious troubles for the ruler and his court (Fash 1983 Volume 1:331; Volume 3, Appendix C:39; Fash and Stuart 1991:173).

In the Petexbatún area in northern Guatemala warfare-related iconography abounds. Iconographically, the costume of Dos Pilas Ruler 3 as represented in stela 2 at Aguateca, signals warfare in a special way. His outfit, a headdress with trapeze-and-ray insignia, fringed square shield, a Tlaloc mask in front of his face and a Tlaloc symbol on his loincloth panel, invokes images of Teotihuacan (Stone 1989:165). It is suggested that the message broadcast here is one of political domination of one site over another, conceivably of Dos Pilas over Seibal, analogous to Uaxactun's Stela 5 message of Tikal's dominance over Uaxactun (Stone 1989:165).

\section{ARCHAEOLOGICAL DATA}

Because of the nature of warfare, we will always be better informed about Maya defensive measures than offensive tactics. The presence of moats and ramparts signal the imminence of war. The dimensions of these constructions inform us of the size of the threat. Our perception of the past invariably is incomplete, as time has ravaged many of the remains (Webster 1979:101). Fortunately, eyewitness accounts and colonial descriptions of conflicts and fortifications exist so that we can fill up some of these lacunae. 
The archaeological data comprise two sets: the physical remains of constructions, and their spatial patterns. Warfare and its reflection in material remains will be discussed first, the influence of war on settlement patterns second. With regard to the material remains, I will initially deal with walls in the Maya area. Then evidence from the Lowlands will be presented with information from the Highlands following. Finally, I will discuss the other functions walls may have had.

Lowlands

Detecting defensive walls is not always easy. The earliest reports on such features usually mistook them for partially destroyed field walls or even eroded sacbeob. Fortunately, the absence of a true rain forest in the northern portion of the Lowlands and the concomitant damage through root action has preserved many of these features. Thanks to modern techniques such as aerial reconnaissance, detection is now easier.

The center of Uxmal was once enclosed by a low wall (Marcus 1993:135). First reported on by Stephens in 1843, very little remains of the wall today (Dunning 1992:168; Dunning and Kowalski 1994:69; Graham 1992: 4:77-78, 83; Kurjack and Andrews 1976:322; Sáenz 1972:36; Stephens 1963:195-196). Allegedly, this wall enclosed some 50 ha (Adams 1981:303). Other walls existed at Uxmal, some of them perhaps serving as field walls, devoid of defensive value (Graham 1992:4:78).

Much better known are the fortifications at Mayapan. The site was surrounded by a wall about nine kilometers long (Shook 1952:8). The stones used in the construction were quarried from nearby outcrops of bedrock. Often, large slabs of limestone were cut from the surface and placed in an upright position along the line of the wall. These slabs formed a retaining wall for a core of dry fill (Shook 1952:9). The outer wall had a parapet, accessible by stairs (Shook 1952:9, 11, 15-16). The wall's height varied between 1.5 and $2.5 \mathrm{~m}$. It is likely, therefore, that it supported a palisade (Shook 1952:19). The precinct containing the temples and the palaces of the elite had its own wall, about $700 \mathrm{~m}$ long. It too consisted of dry masonry.

The interior wall had only two gateways (Armillas 1948:148). The larger, exterior wall had twelve entranceways (Shook 1952:10). They were between one and two meters wide (Armillas 1948:148). The gates varied in complexity, ranging from simple gaps in the wall to a portico-style gate. Gate D is an example of the latter (Shook 1952:11). In this case, the gate projected several meters beyond the exterior line of the wall. A narrow passageway led through this protrusion unto an enlarged rectangular space inside the wall proper. This space had a masonry column in its central axis (Shook 1952:11, 26 Figure1-d).

Mayapan's city walls were constructed during the major occupation as a political center (Shook 1952:18). They may have served to defend the city. Other suggested uses include: delineating the city's (administrative and/or political) boundaries, controlling access to the site for taxation (Shook 1952:19). Mayapan's domestic structures were also walled.

Another well known fortified site is Tulum. It is defended by both a wall and its position along the shore of the Caribbean. The wall, ca. $800 \mathrm{~m}$ long 
surrounds it on three sides, while the cliffs and the sea form a natural barrier on the fourth side (Armillas 1948:148-149). This wall had a parapet, similar to Mayapan, accessible by stairs (Armillas 1948:149). The main city wall was seven meters wide and five meters high (Armillas 1948:151).

North of Tulum, close to the ruins of Xelhá along the Caribbean coast, lies a small fortified peninsula. A single wall bars access to the peninsula from the land side. The wall is about $50 \mathrm{~m}$ long and has one gate, partly protected by a baffle (Armillas 1948:150). The wall was between three to eight meters wide and up to three meters high (Armillas 1948:151).

On the western side of the Yucatán peninsula, in Campeche, lies the site of Champotón. It was surrounded by a wall in dry masonry as well as a moat (Armillas 1948:150). Other fortified, i.e., walled, sites in Yucatán include: Aké (Kurjack and Andrews 1976:322), Chacchob and Ichpaatún in Quintana Roo (Armillas 1948:151). Interpretation of aerial photographs point to fortifications around the site of Chunchucmil in western Yucatán. This was confirmed by recent research (Dahlin 2000).

Chacchob lies north of the Puuc Hills, ca. $15 \mathrm{~km}$ southeast of the modern town of Teabo (Pollock and Stromsvik 1953:82; Webster 1978:376, Figure 1). Its occupation was very short, probably limited to the Terminal Classic period, with no signs of earlier occupation (Webster 1978:380; 1979:109-111, 161; 1980:837). Chacchob was enclosed by a wall, 1.4 km long (Roys 1943:68; Webster 1978:376; 1979:73). The wall enclosed various structures and several sinkholes (Pollock and Stromsvik 1953:84-85; Webster 1978:376). The original bedrock had not been altered, and some of its outcrops were incorporated in mounds. The builders also took advantage of topographical differences to increase the effective height of the wall (Pollock and Stromsvik 1953:85; Webster 1978:377-378; 1979:100; 1980:843). Traces of plaster on parts of the wall suggest it may have been completely plastered (Webster 1978:378, 380; 1979:95).

The wall enclosed the elite residential compound (Webster 1980:835-837). It was coeval with the founding of the town or built very shortly thereafter (Webster 1978:378-380; 1979:98, 103, 161; 1980:835; Hassig 1992:131). The wall was up to two meters high and five to six meters wide (Pollock and Stromsvik 1953:86; Webster 1978:378, 380). The core consisted of large-sized rocks and soil between retaining walls of roughly shaped or natural limestone blocks (Webster 1978:378; 1979:101).

There were three gates, each less than two meters wide (Hassig 1992:131; Webster 1976:98; 1978:376-380; 1979:73, 88-98, 100-101). The gates were filled in and never reopened (Webster 1978:378; 1979:104, 161-162; Hassig 1992:131). These entrances were very simple in design; there were no abrupt turns or other impediments to traffic (Pollock and Stromsvik 1953:86, 96 Figure 1; Webster 1978:378).

The design of the wall at Chacchob was very similar to that of Mayapan: it consisted of an inner bench and a slightly higher outer parapet (Webster 1979:101). The limited height of the parapet makes it likely it was the foundation for a palisade (Pollock and Stromsvik 1953:86). However, there was no evidence of a palisade (Webster 1978:380; 1979:101). The wall at Chacchob represents a major labor expenditure. Its volume is about half of all the non-temple architecture at the site. Webster suggests its construction probably required between one-fifth and one-fourth of all labor expended in construction (Webster 
$1978: 380 ; 1979: 103)$. It is very likely the local work force was reinforced by conscripted labor from outlying settlements (Webster 1978:380; 1979:103).

Northwest of Chacchob lies Cuca, a much larger site (Webster 1978:376, Figure1). It dates to the Terminal Classic period. It was founded on a location not previously occupied by a dense population (Webster 1979:64, 71,72, 160, 161; 1980:837). Cuca was defended by two concentric walls (Hassig 1992:245, n.135; Kurjack and Andrews 1976:319; Webster 1978:382; 1980:838). The outer wall is $2.25 \mathrm{~km}$ long (Webster $1978: 382 ; 1979: 9,59)$. It is still up to two meters high in places, and between six to ten meters wide (Webster 1978:384; 1979:59). This wall enclosed 33 ha. The inner wall which measures $828 \mathrm{~m}$, is up to three meters high in places and is ten to twelve meters wide (Webster 1979:9, 61; 1992:382, 384). The walls protected the organizational center of the site; there is virtually no decrease in density of structures outside the wall (Webster 1978:382; 1979:9).

The inner wall ran over a major structure (Webster 1978:376, Figure 1, 384). The outer wall in places bulged so as to include certain pyramids (Webster 1978:381, Figure 5, 383-384). It is clear that both walls were built to enclose preexisting structures, as well as a cenote (Webster 1978:383; 1979:16, 65, 160; 1980:838-839). This makes the Terminal Classic period a terminus post quem for their construction (Webster 1978:386; Kurjack and Andrews 1976:320; Webster 1979:59, 61).

The wall construction was simple. Dry masonry walls retained limestone rubble (Hassig 1992:130-131; Kurjack and Andrews 1976:319-320; Webster 1976:364; $1978: 382-384 ; 1979: 9,59,61$ ). No gateways are discernible today. Perhaps they were filled up with debris from the collapsing walls, or people entered the site over ramps and stairways (Webster 1978:84-385; 1979:61-62).

The inner and outer zones at Cuca probably served different purposes. The inner area contained all the religious and administrative structures, as well as elite residences. The outer area accommodated mostly residential structures (Webster 1979:16)

The two walls at Cuca clearly differ in the degree and amount of protection they could have provided. Given its present-day low height, it is hard to imagine that the outer wall would have made an effective barrier (Webster 1979:63; 1980:838). The addition of a palisade or a hedge of thorny plants would have achieved that goal, but no traces of such features were found (Webster 1978:385; 1979:63). However, the inner wall did make up a strong barrier. Perhaps the outer wall served as an initial defensive screen, designed to slow the enemy down, while the inner wall was intended to actually shield the site center and its inhabitants (Webster 1978:385; 1979:63). The inner wall was probably built first, and the second wall added later as an outer defensive screen (Webster 1979:71).

Roughly ten kilometers northeast of Cuca lies Aké (Lawrence and Shook 1966:2, Figure 1; Kurjack and Andrews 1976:319, Figure1). This site had defensive walls estimated to enclose a $25 \mathrm{ha} \mathrm{area}^{4}$. They are dated to the Late Classic to Terminal Classic period (Kurjack and Andrews 1976:320, 322). The walls trajectory ran over pre-existing structures, including a sacbe to Izamal (Kurjack and Andrews 1976:322).

Another walled site, Dzonot Aké, lay northeast of Chacchob (Kurjack and Andrews 1976:319, Figure 1). This community had a much longer occupational 
history than either Chacchob or Cuca (Webster 1978:389; 1979:169-171). A single wall enclosed a 6 ha-area, thought to be the core of a much larger site (Webster 1979:112, $114 ; 1980: 840)$

The wall was never more than $2-3 \mathrm{~m}$ in width or $1.5 \mathrm{~m}$ high (Webster 1979:148; 1980:840). It did not completely enclose the community. Instead, it began at the northern edge of a cenote, curved around the site, and then left no trace along the southern edge of the site (Webster 1978:386-387, Figure 9, 388). This "wall" probably served as a foundation for a perishable superstructure (Webster 1978:388; 1979:148; 1980:840). A ditch seems to have run along part of the wall (Webster 1978: 388). The wall postdates the founding of the site, similar to the walls at Cuca (Hassig 1992:131; Webster 1976:364; 1978:388; 1979:149). It was one of the latest constructions on the site. It enclosed three small elite residential groups squatting among the ruins of a much larger and older center (Webster 1980:840).

Less than 20 kilometers southwest of Cuca lies Muna. Traces of a wall remain today, enclosing a 25 ha area. This defensive feature was dated to the late to terminal Classic period (Kurjack and Andrews 1976:320).

Oxpemul is classified as a hilltop fortress. Its main component occupies the top of a hill, with a steep slope of at least 17 meters (Adams 1981:234; Ruppert and Denison 1943:Plate 67). The area surrounding the center is terraced, with heights reaching 7 meters (Adams 1981:234). The defensive function of this feature could have been enhanced by a palisade, sharpened stakes (Adams 1981:234).

The site of Las Victorias, south of Tzibanché, is located on an east-facing natural slope. Several hectares are enclosed by right-angled walls that follow the slope contour and cross at right angles to it, thus forming a rectangular compound in which mounds are enclosed. The walls are constructed of rough rock rubble and reach over two meters in height, reminiscent of those on the coast at Ichpaatun, but lower and less well preserved than those of Tulum. Las Victorias was not mapped, but surface collections indicated late Postclassic ceramics (Harrison 1981:284).

A site whose fortifications made people rethink the long-accepted peaceful nature of the Maya was Becan in Campeche. The fortification was built at the end of the Preclassic, and probably served as a barrier well into the Late Classic period, when the ditch was widened (Webster 1976:1, 101, 103). Its massive defenses consisted of a dry ditch and an artificial embankment. The ditch was $1890 \mathrm{~m}$ long and surrounded the site's center (Webster 1976:8, 14). Seven causeways across the ditch provided access to the site was gained. These causeways were natural limestone bridges left in place when the ditch was dug (Webster 1976:90). The bridges were not pierced to let water through, nor was the ditch lined, confirming the ditch had never held water (Webster 1976:90). Ruppert and Denison, who found the site, claimed that the ditch varied in width between three and twenty-five meters, and was between two and four meters deep (Armillas 1948:152; Ruppert and Denison 1943:54). Webster's measurements range from 12 to $27 \mathrm{~m}$ wide (Webster 1976:14).

The defenses were farther strengthened by an artificial embankment built along the inner edge of the ditch (Webster 1976:8, 14, 88). Originally, this parapet was $2 \mathrm{~m}$ high, which meant that any attacker was faced with a barrier more than $11 \mathrm{~m}$ high (based on an average ditch depth of $9 \mathrm{~m}$ ) (Webster 1976:89). 
No traces of any wooden palisade were found, although Webster surmises there must have been one (Webster 1976:89). Large, ceremonial architecture inside the ditch may have added a desirable elevated platform for any defender (Webster 1976:93). Although excavations yielded no evidence of a successful attack on the site, it is safe to assume that, in times of danger, the causeways may have been barricaded or even cut (Webster 1976:95). Based on the scale of the defenses, Webster suggested that a successful hostile force would have required between 3000 to 4000 men to subdue the site (Webster 1976:96).

The site of Edzná in Campeche possessed a feature known as the "Fortress." This rectangular area, delineated by a moat, lay south of the site's center and measured about $500 \times 30 \mathrm{~m}$ (Matheny et al. 1980b: Map sheet 9). Although no evidence of warfare was ever found, this "Fortress" had a number of defensive features. The area was surrounded by a moat, $1873 \mathrm{~m}$ long (Matheny et al. 1980a:191). Access was possible via a causeway raised about three meters above the bottom of the north moat, or by canoe (Matheny et al. 1980a:169). The causeway narrowed at its passage through the moat, and its banks sloped steeply on either side (Matheny et al. 1980a:169). A 10-m high structure in the center of the "Fortress" did provide an excellent vantage point to observe the immediate surroundings. Furthermore, at the end of the causeway, two low mounds located on the causeway's centerline could have served as the "Fortress'" gate (Matheny et al. 1980a:169). Ceramics dated the structures inside the "Fortress" to the Late Preclassic Period, the same period during which the Becan defensive works were built (Matheny et al. 1980a:191; Webster 1976:103).

Aguacatal, a peninsular site in western Campeche, also relied on water as a defensive barrier. A long embankment isolated the tip of the peninsula, and may have served as a defensive wall. It has tentatively been dated to the Late Classic and Postclassic period. There was no moat, probably due to the high water table in the area. (Matheny 1970; Webster 1976:101).

Research conducted farther south in the Peten has unveiled the existence of numerous defensive features. The most famous ones are the earthworks north and south of Tikal. This Maya metropolis had an earthen wall and ditch at about $4.5 \mathrm{~km}$ north of the center of the site. The wall and dry ditch were $9.5 \mathrm{~km}$ long, with swamps at either end (Puleston and Callender 1967:43). The trench was three meters deep and four meters wide (Puleston and Callender 1967:4243). It lay on the north side of the wall (Puleston and Callender 1967:40).

There were four or five gaps in the wall and ditch system, probably serving as entranceways (Puleston and Callender 1967:43). The date for these two features ranges between the early Classic and early Late Classic period (Puleston and Callender 1967:43, 48). Another wall located some $8 \mathrm{~km}$ south of Tikal's center (Rice and Rice 1981:272).

The function of both systems remains open to suggestions. In both cases, they were too far away from the site and too long to have been continuously guarded. Therefore, it is possible these earthworks were intended to delay aggressors long enough to alert the city, and to funnel them along certain routes where they could then be attacked (Webster 1976:367; Hassig 1992:78). Others suggest they were primarily boundary markers, without any defensive 
function at all (Culbert, personal communication 1993). Perhaps they served to levy taxes on commercial traffic in and out of the city (Puleston and Callender 1967:43).

At Calakmul, there is a 200-meter segment of a wall (Ruppert and Denison 1943:22). It lies in the northwestern part of the city. The wall still stands 6.15 meters high, and is about 2 meters thick. Another possible wall (Ruppert and Denison 1943:Plate 61) runs north next to the quarry area (Adams 1981:234). Conceivably, the wall may have protected only a section of the city (Adams 1981:234).

South of Calakmul, at El Mirador, Graham reported on a $600-\mathrm{m}-1$ ong wall at the site (Adams 1981:234; Graham 1967:Figure 29). Richard Hansen informed me that there were additional massive fortifications around the site, consisting of dry ditches and ramparts, similar to Becan (Hansen, personal communication 1993).

Lundell reported the existence of "two walls, each approximately 150 meters in length, forming a main entrance to the central plaza" at the site of Polol (Lundell 1934:177). Polol is located seven kilometers south of the modern community of La Libertad, El Petén, Guatemala (Lundell 1934:175), about half way between Flores and Sayaxché. These walls do not enclose any structures, and therefore must have had a non-defensive function (Lundell 1934:180, Figure 3).

Finally, we turn to the Petexbatún region, which abounds with fortified sites such as Aguateca, Dos Pilas and Punta de Chimino. Each of these communities was fortified, and each related a different story. Dos Pilas was essentially defended by wall systems, Aguateca combined walls with natural topography such as the escarpment and the grieta running through the site, and finally, Punta de Chimino had massive ditch and rampart systems, as well as the lake to defend itself.

Perhaps the most dramatic of all fortifications are the walls at Dos Pilas. Two portions of the site were protected: the main plaza, and Structure P5-7, known as "El Duende," a temple complex east of the plaza (Houston 1987:384-385). Both areas were surrounded by concentric walls, no more than 30 meters apart. "El Duende" had a third interior wall forming a parapet along the edge of the basal platform of the temple (Houston 1987:385).

The walls are modest in appearance. They are preserved up to a meter in height and width in most places. The construction material was local fieldstone, although some construction materials had been incorporated as well. Portions of structure L5-33, south of the main plaza, had been dismantled and re-used in the wall superimposed on it (Houston 1987:385). This superposition of wall and architecture is a feature unique to Dos Pilas, it does not occur at Aguateca, or anywhere else in the Petexbatún.

Access to the plaza area occurred via simple gaps in the wall. The only possible exception is what could have been a baffled gate some $35 \mathrm{~m}$ south of the "El Duende" complex (Houston 1987:385-386). Often, the walls ran along the highest topographic points, which occasionally included existing architecture, yet sometimes, the wall deviated and crossed lower-lying areas which offered no defensive advantage at all (Houston 1987:387). Three test pits were dug into the wall: DP 11A, DP 11C, and DP 11D. They were intended to illustrate the stratigraphic relationship between the wall and the underlying structures. Sub operation DP 11A uncovered Hieroglyphic Stairway no. 4, with the wall 
bisecting it (Symonds et al. 1991:239-258). In all cases, there is no humus between the walls and the underlying structures, indicating that the walls were built while the structures were still in use, or immediately after they were abandoned (Symonds et al. 1990:239).

The walls may have had a perishable superstructure. They were built hastily as illustrated by the superposition of wall and architecture and the quarrying of monuments for construction materials. The areas they enclosed were small: about 4 ha in the main plaza, and about 3.5 ha at the El Duende complex (Houston 1987:385).

Aguateca's defenses were laid out much more carefully and took advantage of the topography. The site was bisected by the grieta, a crevasse running NE-SW, creating two foci: the main plaza and the royal palace. The main plaza lay to the west of the grieta, the palace groups were built east of the grieta, between this feature and the escarpment (Beekman 1991:398-399; Inomata 1991). This plaza was protected by four sets of walls. All walls around the plaza, except the exterior one, define a well-circumscribed space, using the grieta as a starting and ending point. The exterior wall started by the grieta, in the south, and then arched west and eventually north. It suddenly stopped in flat terrain. Perhaps it was intended to continue farther north and to link up with the grieta as well (Inomata 1991:409).

The second focus of occupation was even better protected. The royal palace group, the avenue leading up to it, and the structures on either side of it lay to the east of the chasm and the escarpment to the west. To these impressive natural defensive features walls were added. Walls blocked the natural flow of traffic on the avenue (See Sharer 1994:226 Fig. 5.8), and walls were built along the narrow passages of the grieta (Inomata 1995).

At Punta de Chimino the defenses consisted of three large parallel moats cutting off the base of the peninsula, effectively transforming it into an island. The lake itself provided protection as well. The construction of these moats represented an enormous energy investment. Their size speaks eloquently of the magnitude of the perceived threat. Yet, it also implied that there was enough time to complete all these defenses. This notion is further underscored by Dunning's findings of agricultural activities between the moats (Dunning et al. 1991:842). Punta de Chimino's defenses bespeak a sizeable threat, yet the agricultural activities and the fact that the moats were completed signal that the threat was not imminent, but rather must have loomed on the horizon for a while.

Highlands

Our archaeological knowledge of fortified sites in the Maya Highlands is often amplified by the chronicles left behind by the Conquistadores. Most sites took refuge behind walls, usually on a promontory. Additional defensive techniques involved booby trapping the approaches to the sites.

An example of the latter occurred at Cehaché, whose inhabitants had its access roads booby trapped. For its protection, the site further relied upon 
topography and two walls separated by a moat (Armillas 1948:151-152). The interior wall had towers up to six meters high at regular intervals (Armillas 1948:152).

A number of Postclassic sites in the Highlands of Guatemala were built with their defense in mind. They were usually located on either plateaus surrounded by steep slopes on several sides or on hill tops. Examples are Zaculeu, Rabinal, Utatlán, Iximché, Chutix-Tiox and Rio Blanco (Armillas 1948:152), and Cambote (Woodbury and Trik 1953:23).

Zaculeu was built on a promontory. Access was possible only along a narrow land bridge. This and the steep slopes of the promontory create a very defensible location (Boggs 1946:1; Woodbury and Trik 1953:16, 23). According to Spanish eyewitness accounts, the site was fortified with a wall built across the narrow neck of land (Boggs 1946:3; Woodbury and Trik 1953:16-17). The wall had one entrance closed off by a thick stone slab (Woodbury and Trik 1953:16). Apparently, the site was defended by a number of bulwarks. They were placed at particular strategic points. They included a ditch, with the earth used to build up a wall behind it strengthened by timbers (Woodbury and Trik 1953:17).

The site of Utatlán was located on a promontory, protected by steep slopes on all but one side (Fuentes y Guzmán 1951:23, 59). It had only one entrance (Boggs 1946:2). Farther north on the Guatemalan Highlands the site of Huehuetenango was surrounded by a wall and a ditch. We do not know whether this wall was made out of stone or wood (Woodbury and Trik 1953:15). The town of Mazatenango had a wall and wall around it. The wall consisted of earth and wood (Woodbury and Trik 1953:14-15).

Iztacamaxtitlan was a hill top site fortified with a wall, barbicans and ditches (Armillas 1948:153). Associated with the site, in the valley was a wall blocking access to the valley, two and a half meters in height, and ca. six meters wide. It had a breastwork on top, enabling soldiers to take cover and fight from an advantageous position (Armillas 1948:153-154).

Iximché occupied an easily defensible position. It was built on a promontory. Steep slopes protected it on two sides, while a ditch and associated wall cut off access from the plateau side (Fuentes y Guzmán 1951:23; Guillemin 1965:1415; Villacorta and Villacorta 1927; 103-104). The wall may have been up to three meters high (Guillemin 1965:15). Its gate had two doors (Guillemin 1965:40). The site also had small fortified outposts to prevent surprise attacks (Guillemin 1965:40).

\section{CONCLUDING REMARKS ON MAYA WARFARE}

The data presented in the preceding pages permit us to reconstruct Maya warfare. Archaeological and historic sources have helped to identify various forms of warfare, some of which may not leave any imprint at all in the material record. Inscriptions also shed light on the pertinent details and the seasonality of war. Finally, the interaction between all this information and settlement pattern studies help define the role played by war in the political organization of Maya society. 


\section{Warfare and its visibility in the material record}

As we seek to improve our understanding of precolumbian conflict resolution, we must be aware of the limitations imposed on our search. Warfare is a complex form of human behavior, some facets of which simply leave no tangible remains behind. Other aspects of warfare can be surmised only indirectly, such as, for example, the purported seasonality of wars, or efforts to mitigate conflict.

Population nucleation, especially in hilltop sites, and walled sites are a common phenomenon in the Maya area. Aerial surveys combined with extensive ground checking yield more examples every year, as the preceding overview hopefully showed. Walls and moats are visible expressions of fear, and this fear is often translated into huge tangible defensive measures, such as moats and masonry walls. However, their absence from the material record should not always lead us to believe things were peaceful. Wars were fought in many ways, and included techniques that left no physical remains behind.

Written sources tell us of palisades in the Maya area. The Maya referred to them as tulumché (Armillas 1948:141). Sometimes people would dig holes in the road, place sharp sticks in these holes and then cover everything up with branches (Armillas 1948:151, 156). Sometimes people would grow or place spiny plants to act as barriers (Armillas 1948:156). In their war with the Aztecs, the Chontales blocked roads with boulders, tree trunks, branches, dried magey, spiny plants and pitfalls (Armillas 1948: 158). Moctezuma had one of the access roads to Tenochtitlan blocked with a wall of maguey plants (Anderson and Dibble 1978:26-27). The Quiché of highland Guatemala employed a fighting technique which left behind no traces either: they threw gourds full of wasps among the enemy to disrupt them (Carmack 1968:79-80).

\section{Seasonality of warfare}

Pre-industrial warfare was limited not only by logistical constraints, but also by cyclical natural phenomena. The agricultural cycle caused the man to prefer certain months to engage in conflict. Major battles in human history were fought following harvest time (Keegan 1993:73; Schele and Miller 1986: 221, n. 8; Vayda 1976:16-17). Proskouriakoff suggested this trend also applied to the Maya, referring to sculptured panel 4 at Altar de Sacrificios. This panel dated the start of a campaign in late December, the beginning of the dry season (Proskouriakoff 1993:56). Epigraphic information on warfare supports this idea. Before discussing these data, we need to remind ourselves that this seasonality is caused by several factors, which probably reinforce each other.

The Maya did not have a standing army. Arlen Chase (1994:45) suggested that the Late Classic Maya middle class owed their success to participation in warfare. Moreover, Chase (1994:41) posited that some of these middle class people, at least at Caracol, had interests in agriculture. It therefore follows that the times when these people can engage in warfare is closely tied the agricultural calendar. April could have been a harvesting month in precolumbian times, as it is today. Afterwards, there was time for warfare. 
Logistical problems forced the generals to favor the dry period over the rainy season. Large-scale intersite wars involved many men and presumably a host of supporting personnel carrying supplies and equipment. Such a crowd can only move successfully during the dry season, when the trails are dry, and not too many tree falls block the roads. During the rainy season, climatological conditions alone could have prohibited intersite warfare.

Finally, we know that the Maya sometimes timed their wars according to the astronomical considerations, related to Venus and Jupiter/Saturn stations (See Schele and Freidel 1990:44-446, n. 47). Such considerations favored action during the months of December and January, farther reinforcing the agricultural and climatological cycle.

Maya texts referring to dated warfare events support the suggestion of seasonality in warfare. Warfare is waged primarily during the dry season, from December until April.

This seasonal trend becomes even more evident when we differentiate between the capture and defeat events, as identified above. These following remarks are based on a number of presumptions: capture refers to the taking prisoner of an individual, while defeat refers to large-scale warfare between sites, entailing a difference in manpower involved. Prisoners could be taken by small raiding parties, ambushing unsuspecting victims, whereas the defeat of a site requires a host of warriors. When we differentiate between these two types of hostile exchanges, the suggestion of seasonality is reinforced.

In July and August, only a few intersite wars occurred, and most of the hostile acts in these months were probably small-scale raids aimed at capturing individuals.

The data from Yaxchilán for which we have many more dated occurrence of warfare, supports the contention that warfare was a rare event during the rainy season. For the period between 564 to 808 A. D., there are two capture events and one war episode in July.

These data show that Maya warfare was limited not only because of logistical problems, but also because of a preoccupation with agricultural, climatological, and astronomical considerations. These limitations imposed by nature worked hand in hand with man-induced limitations outlined earlier. However, I suggest there was at least one more limiting factor, and that was the ballgame (Leyenaar and Van Tuerenhout s.d.)

\section{Rules of warfare and Late Classic Maya behavior on the battlefield}

The introductory part of this presentation dealt with limitations on warfare. I outlined how several factors, both man-made and natural, mitigate some aspects of warfare. These limiting factors tend to have a stabilizing influence on the conduct of war, until a technological breakthrough pushes back the natural impediments on warfare. Man-made restrictions are prone to change as well, especially when new technology requires a new appraisal of what is acceptable and what is not. The laws of war and constraints on warfare have been on people's minds for centuries (Howard et al. 1994). 
While it is impossible to completely reconstruct prehistoric battlefield behavior, nor even to ascertain what, if any, the restrictions were that applied in prehistoric warfare, the material correlates of war indirectly inform us what some of that behavior may have been. Fortifications are a main source of information in this regard.

Their presence implies warfare and instability, their absence could imply political stability and an absence of warfare. Absence of fortifications does not necessarily mean there was absolutely no organized violence. Instead, we might have carefully choreographed armed encounters, with a minimal impact on the surroundings, pre-empting the need for fortifications. The appearance of fortifications in regions where none had ever existed before or the re-emergence after a long absence herald important changes in battlefield comportment. Studies of pre-industrial societies, and their adherence limitations on warfare have shown how developments in methods, techniques and equipment dramatically changed the conduct of war. These reinterpretations invite us all to also re-evaluate the law of arms. 


\section{REFERENCES CITED}

ADAMS, R. E. W. 1981, Settlement Patterns of the Central Yucata $n$ and Southern Campeche Regions. In Lowland Maya Settlement Patterns, edited by W. Ashmore, pp. 211-257. University of New Mexico Press, Albuquerque.

ADAMS, R. E. W., and JONES, R. C. 1981, Spatial patterns and regional growth among Classic Maya cities American Antiquity 46(2):301 - 322.

ANDERSON, A. J. O., and CH. E. DIBBLE, 1978, The War of Conquest. How It Was Waged Here in Mexico. The Aztecs' Own Story As Given To Fr. Bernardino de Sahagún. The University of Utah Press, Salt Lake City.

ARMILLAS, P. 1948, Fortalezas Mexicanas. Cuadernos Americanos 41(5):143-163.

BAIRD, E. T., 1989, Stars and War at Cacaxtla. In Mesoamerica After the Decline of Teotihuacan. A.D. 700 - 900, edited by R. A. Diehl, and J. C. Berlo. pp. 105-122. Dumbarton Oaks Research Library and Collection, Washington, D.C.

BEEKMAN, CH. 1991, Levantamiento del mapa y patrones de asentamiento. In Proyecto arqueológico regional Petexbatún. Informe preliminar \# 3. Tercera temporada 1991, edited by A. Demarest, T. Inomata, H. Escobedo, and J. Palka, pp. 398-403. Vanderbilt University, Nashville.

BERLO, J. C. 1989 , Early Writing in Central Mexico: In Tlilli, In Tlapalli before A.D. 1000. In Mesoamerica After the Decline of Teotihuacan. A.D. $700-900$, edited by R. A. Diehl, and J. C. Berlo, pp. 19-47. Dumbarton Oaks Research Library and Collection, Washington, D.C.

BOGGS, S. 1946, Guia de las Ruinas de Zaculeu. Departemento de Huehuetenango, Guatemala. Guatemala.

CARMACK, R. M. 1968, Toltec Influence on the Postclassic Culture History of Highland Guatemala. Middle American Research Institute, Publication No. 26. Tulane University, New Orleans.

CHASE, A. 1994, Elites and the changing organization of Classic Maya society. In Mesoamerican elites. An archaeological assessment, edited by D. and A. Chase, pp. 31-49. University of Oklahoma Press, Norman.

CHASE, A. F., and D. Z. CHASE, 1987, Investigations at the Classic Maya City of Caracol, Belize:1985-1987. Pre-Columbian Art Research Institute Monograph No. 3. San Francisco.

COGGINGS, C.

1980, The Shape of Time: Some Political Implications of a Four-Part Figure. American Antiquity 45(4): 727-739. 
1984, Murals in the Upper Temple of the Jaguars, Chichén Itzá. In Cenote of Sacrifice. Maya Treasures from the Sacred Well at Chichen Itzá, edited by C. L. C. Coggins, and O. C. Shane III, pp. 156-165. University of Texas Press, Austin.

CULBERT, T. P.

1988, Political History and the Decipherment of Maya Glyphs. Antiquity 62:135152.

1991, Polities in the northeast Peten, Guatemala. In Classic Maya political history: hieroglyphic and archaeological evidence, edited by T. P. Culbert, pp. 128-146. A School of American Research Book. Cambridge University Press, Cambridge.

DAHLIN, B. 2000, The barricade and abandonment of Chunchucmil: Implications for Northern Maya warfare. Latin American Antiquity 11 (3), pp. 283-298.

DUNNING, N., 1992, Lords of the Hills: Ancient Maya Settlement in the Puuc Region, Yucatán, Mexico. Monographs in World Archaeology No. 15. Prehistory Press, Madison.

DUNNING, N. and J. K. KOWAISKI, 1994, Lords of the Hills: Classic Maya settlement patterns and political iconography in the Puuc Region, Mexico. Ancient Mesoamerica 5(1):63-95.

FASH, W. L. 1983 , Maya state formation: a case study and its implications. Unpublished Ph.D. dissertation. Department of Anthropology, Harvard University.

FASH, W. L., and D. STUART, 1991, Dynastic History and Cultural Evolution at Copan, Honduras. In Classic Maya Political History, edited by P. T. Culbert. pp. 147-179. School of American Research, Cambridge University Press, Cambridge.

FONCERADA DE MOLINA, M. 1965, La escultura arquitectónica de Uxmal. Estudios y Fuentes del Arte en Mexico No. 20. Instituto de Investigaciones Estéticas, Universidad Nacional Autónoma de México, Mexico.

FOX, J.W.

1987, Maya Postclassic state formation. Cambridge University Press, Cambridge.

1989, On the Rise and Falls of Tuláns and Maya Segmentary States. American Anthropologist 91(3):656-681.

FUENTES Y GUZMAN, F.A. de, 1951, Historia de Guatemala; o recordación florida. Bibliotheca de Cultura Popular Vol.9. Guatemala.

Guillemin, J. F. 1965, Iximché. Capital del antiguo reino Cakchiquel. Publicaciones del Instituto de Antropología e Historia de Guatemala, Guatemala.

GRAHAM, I.

1967, Archaeological Explorations in El Petén, Guatemala. Middle American Research Institute. Publication No. 33. Tulane University, New Orleans.

1982, Yaxchilan. In Corpus of Maya Hierglyphic Inscriptions, vol. 3, part 3. Peabody Museum of Archaeology and Ethnology. Harvard University, Cambridge. 
1986, Uaxactun. In Corpus of Maya Hieroglyphic Inscriptions, vol. 5, part 3. Peabody Museum of Archaeology and Ethnology. Harvard University, Cambridge. 1992, Uxmal. In Corpus of Maya Hieroglyphic Inscriptions, vol. 4, part 2. Peabody Museum of Archaeology and Ethnology. Harvard University, Cambridge.

HAMMOND, N. 1991, Introduction. In Classic Maya political history: hieroglyphic and archaeological evidence, edited by T. P. Culbert, pp. 1-18. A School of American Research Book. Cambridge University Press, Cambridge.

HARRISON, P. 1981, Some Aspects of Preconquest Settlement in Southern Quintana Roo, Mexico. In Lowland Maya Settlement Patterns, edited by W. Ashmore, pp.259-286. University of New Mexico Press, Albuquerque.

HASSIG, R. 1992, War and Society in Ancient Mesoamerica. University of California Press, Berkeley.

HOUSTON, S. D. 1987, The Inscriptions and Monumental Art of Dos Pilas, Guatemala: A Study of Classic Maya History and Politics. Unpublished Ph.D. dissertation. Department of Anthropology, Yale University.

HOWARD, M., G. J. ANDREOPOULOS AND M. R. SCHULMAN (editors), 1994, The Laws of War. Constraints on Warfare in the Western World. Yale University Press, New Haven.

INOMAtA, T. 1991, Reconocimiento alrededor de Aguateca. In Proyecto arqueológico regional Petexbatún. Informe preliminar \# 3. Tercera temporada 1991, edited by A. Demarest, T. Inomata, H. Escobedo, and J. Palka, pp. 405-410. Vanderbilt University, Nashville.

JOHNSTON, K. 1985, Maya dynastic territorial expansion: glyphic evidence for Classic centers on the Pasión river. Palenque Round Table Series 7:49-56.

KEEGAN, J. 1993 , History of Warfare. Alfred A. Knopf, New York.

KOWALSKI, J. K. 1987, The House of the Governor: A Maya Palace of Uxmal, Yucatan, Mexico. University of Oklahoma Press, Norman.

KUBLER, G. 1962,The art and architecture of ancient America: the Mexican, Maya and Andean peoples. Penguin Books, Baltimore.

KURJACK, E. B., and E. WYLLYS ANDREWS V. 1976, Early Boundary Maintenance in Northwest Yucatan, Mexico. American Antiquity 41:318-325.

LAWRENCE, R., and E. M. SHOOK, 1966, Preliminary report on the ruins of Aké, Yucatán. Society for American Archaeology, Memoir No. 20. Washington, D.C.

LEYENAAR, T. J. J. and D. Van TUERENHOUT, s.d., The ballgame: a mitigating factor in Precolumbian Maya warfare? Rijksmuseum voor Volkenkunde. Leiden, in press. 
L. de RUIZ, D. LOPEZ de MOLINA, AND D. MOLINA FEAL (editors), 1986, Cacaxtla. El lugar donde muere la lluvia en la tierra, Instituto Nacional de Antropología e Historia, México, D.F.

LOUNSBURY, F. 1982, Astronomical knowledge and its uses at Bonampak, Mexico. In Archaeoastronomy in Precolumbian America, edited by A. Aveni, pp. 143-168. University of Texas Press, Austin.

LUNDELL, C. L. 1934, Ruins of Polol and other archaeological discoveries in the department of Peten, Guatemala. Carnegie Institution of Washington. Publication 436. Contributions to American Archaeology No. 8. Carnegie Institution, Washington, D.C.

MARCUS, J.

1976, Emblem and State in the Classic Maya Lowlands: An Epigraphic Approach to Territorial Organization. Dumbarton Oaks, Washington, D.C.

1992, Mesoamerican Writing Systems. Propaganda, Myth, and History in Four Ancient Civilizations. Princeton University Press, Princeton.

1993, Ancient Maya Political Organization. In The Peak of Lowland Maya Civilization: New Understandings of Eighth Century Maya Development, edited by J. Sabloff and J. Henderson. Dumbarton Oaks. Washington, D.C.

MATHENY, R. T. 1970, The Ceramics of Aguacatal, Campeche, Mexico. New World Archaeological Foundation, Brigham Young University, Provo.

MATHENY, R. T., D. L. GURR, D. W. FORSYTH, and R. HAUCK

1980a, Investigations at Edzná Campeche, Mexico. Papers of the New World Archaeological Foundation No. 46, Vol. 1, part 1: The hydraulic system. New World Archaeological Foundation, Brigham Young University, Provo.

1980b, Investigations at Edzna Campeche, Mexico. Papers of the New World Archaeological Foundation. No. 46, Vol. 1, part 2: Maps. New World Archaeological Foundation, Brigham Young University, Provo.

MATTHEWS, P. 1985, Maya Early Classic Monuments and Inscriptions. In A Consideration of the Early Classic Period in the Maya Lowlands, edited by G. Willey and P. Matthews, pp. 5-54. Institute for Mesoamerican Studies, State University of New York, Albany.

McVICKER, D. 1985, The Mayanized Mexicans. American Antiquity 50: 82-101.

MILLER, A. G. 1977, "Captains of the Itza" Unpublished mural evidence from Chichen Itza. In Social Process in Maya Prehistory, Essays in Honour of Sir J. Eric S. Thompson, edited by N. Hammond, pp. 197-225. Academic Press, New York.

MILLER, M. E. 1995, Maya Masterpiece Revealed at Bonampak. National Geographic Magazine (187) 2: 50-69.

MLLER, M. E., and S. D. HOUSTON, 1987, The Classic Maya ballgame and its architectural setting: a study of relations between text and image. Res 14:47-65. 
POLLOCK, H. E. D. 1980, The Puuc, an Archaeological Survey of the Hill Country of Yucatan and Northern Campeche, Mexico. Peabody Museum of Archaeology and Ethnology Memoirs, Vol. 19. Harvard University, Cambridge.

POLlOCK, H. E. D. and G. STROMSVIK, 1953, Chacchob, Yucatan. Carnegie Institution of Washington, Current Reports 1(6):82 - 101.

PROSKOURIAKOFF, T.

1963, Historical data in the inscriptions of Yaxchilan. Part 1. Estudios de Cultura Maya 3:149-167.

1993, Maya history, edited by R. Joyce. University of Texas Press, Austin.

PUleston, D. F., and D. W. CALLENDER, 1967, Defensive earthworks at Tikal. Expedition 9:40-48.

RICE, DON S., and P. M. RICE, 1981, Muralla de Leon: A Lowland Maya Fortification. Journal of Field Archaeology 8:271-288.

RIESE, B.

1982, Kriegsberichte der klassischen Maya. Baessler-Archiv. N.F. XXX:255-321.

1984, Hel hieroglyphs. In Phoneticism in Mayan Hieroglyphic Writing, edited by J. S. Justeson and L. R. Campbell, pp. 263-286. Institute for Mesoamerican Studies, State University of New York, Albany.

ROBLES, CASTELLA J. F., and A. P. ANDREWS, 1986, A review and synthesis of recent Postclassic archaeology in northern Yucatan. In Late Lowland Maya Civilization: Classic to Postclassic, edited by J. Sabloff and E. Wyllys Andrews V, pp. 53-98. University of New Mexico Press, Albuquerque.

ROYS, R. L. 1943, The Indian background of colonial Yucatan. Carnegie Institution of Washington. Publication 548. Carnegie Instit, Washington, D.C.

RUPPERT, K., and J. H. DENISON, 1943, Archaeological reconnaissance in Campeche, Quintana Roo, and Peten. Carnegie Institution of Washington. Publication 602. Carnegie Institution, Washington, D.C.

SÁENZ VARGAS, C. A. 1972, Exploraciones y restauraciones en Uxmal (1970 1971). Boletín del Instituto Nacional de Antropología e Historia 2:31 - 40.

SCHELE, L., and M. E. MILLER, 1986, The Blood of Kings: Dynasty and Ritual in Maya Art. George Braziller, New York, and Kimbel Art Museum, Fort Worth.

SCHELE, L. and D. FREIDEL, 1990, A Forest of Kings. the Untold Story of the Ancient Maya. William Morrow, New York.

SHARER, R. J. 1994, The Ancient Maya. 5th ed., Stanford.

SHOOK, E. M. 1952, The great wall of Mayapan. Carnegie Institution of Washington, Current Reports 1(2):7-35. 
STEPHENS, J.L. 1963 [1841], Incidents of Travel in Yucatan. Dover Publications, New York.

STONE, A. 1989, Disconnection, foreign insignia and political expansion: Teotihuacán and the warrior stelae of Piedras Negras In Mesoamerica After the Decline of Teotihuacán, A.D. $700-900$, edited by R. A. Diehl and J. C. Berlo, pp 153 - 172. Dumbarton Oaks Research Library and Collection. Washington, D.C.

STUART, D.S.

1992, Hieroglyphs and archaeology at Copan. Ancient Mesoamerica 3(1):169-184.

1993, Historical Inscriptions and the Maya Collapse. In Lowland Maya Civilization in the Eighth Century A.D., edited by J. A. Sabloff and J. S. Henderson, pp. 321-354. Dumbarton Oaks Research Library and Collection, Washington, D.C.

SYMONDS, S., B. ARROYO, and S. D. HOUSTON, 1990, Operacion DP11: Investigaciones en al Palacio de Dos Pilas. In Proyecto Arqueológico Regional Petexbatún. Informe Preliminar \#2. Segunda Temporada 1990, edited by A. A. Demarest and S. D. Houston, pp. 235-275. Vanderbilt University, Nashville.

TATE, C. 1992, Yaxchilan. The design of a Maya ceremonial city. University of Texas Press, Austin.

VAYDA, A. 1976, War in Ecological Perspective: Persistence, Change, and Adaptive Processes in Three Oceanian Societies.Plenum, New York.

WEBSTER, D.

1978, Three Walled Sites of the Northern Maya Lowlands. Journal of Field Archaeology 5:375-390.

1979, Cuca, Chacchob, Dzonot Aké: Three Walled Northern Maya Centers. Occasional Papers in Anthropology, No. 11. Department of Anthropology, The Pennsylvania University.

1980, Spatial Bounding and Settlement History at Three Walled Northern Maya Centers. American Antiquity 45(4):834-844.

WOODBURY, R. B., and A. S. TRIK, 1953, The Ruins of Zaculeu, Guatemala. Guatemala

WREN, L., and P. SCHMIDT, 1991, Elite interaction during the Terminal Classic period: New evidence from Chichen Itza. In Classic Maya political history: hieroglyphic and archaeological evidence, edited by T. Patrick Culbert, pp. 199-225. A School of American Research Book. Cambridge University Press, Cambridge. 
Dirk Van Tuerenhout

\section{NOTES :}

${ }^{1}$ Other instances of the "ax-event" glyph are listed in Riese (1982:274).

${ }^{2}$ Three radiocarbon dates have been reported in association with the mural paintings: $755 \pm 75$ A.D. years, wooden lintel, Structure A; $744 \pm 91$ years A.D., level xviii, substructure, Structure B; $649 \pm 93$ A.D. years, level x, substructure Structure B (López de Molina 1981:173). Additional radiocarbon dates range between 194 and 792 A.D. (Ruiz et al. 1986:Appendix 1).

${ }^{3}$ Construction continued after the walls were built. At least one structure, Str. VII, conformed to the preexisting inner wall (Webster 1979:12).

${ }^{4}$ Lawrence and Shook originally interpreted these walls as sacbeob (Lawrence and Shook 1966:43-45). Additional reconnaissance by Kurjack and Andrews identified them as defensive walls (Kurjack and Andrews 1976:320). 